\title{
Analysis of Urban Male Consumers Attitude and Behavioral Intention Towards Skincare Product in Indonesia
}

\author{
Rhey Tyas Ferry, Rifelly Dewi Astuti
}

Faculty of Economics and Business, Universitas Indonesia, Salemba, Jakarta Pusat, 10440, Indonesia rheytyas@gmail.com,rifelly.dewi@ui.ac.id

\begin{abstract}
This study aims to examine the phenomenon of male consumers buying skincare as a product category which traditionally evolve in women market segmentation. The main purpose was to find the most influential variables from three dimensions, namely personal (i.e., self-image congruity, ageing effect, physical attractiveness, healthcare), socio-cultural (i.e., social beliefs, lifestyle), and marketing (i.e., social media advertising, celebrity endorsement, online purchase situation, price value) factors on their consumption behavior towards skincare products. It is a descriptive survey research using questionnaires distributed to men living in urban areas and 384 male consumers were collected. SEM (Structural Equation Modelling) analysis was used to test the hypotheses. Results showed that ageing effect has the strongest impact, and on the contrary, celebrity endorsement has the weakest impact on urban male consumer attitude towards skincare products. Despite the common beliefs that the cosmetic industry associated with women, this paper has proven that by using the right tools and variables, this niche market segmentation brings up enormous potential for the beauty industry in Indonesia. Findings in this study provide insights for marketers in Indonesia about what key factors to consider when it comes to men skincare product categories, especially if they want to penetrate the urban area segmentation.
\end{abstract}

Keywords: Male consumer, Skincare, Attitude, Repurchase Intention.

\section{INTRODUCTION}

Beauty industry has been one of the most promising sectors. Traditionally, the segmentation comes from women. On the other hand, an "underdog" market has emerged and increasingly growing in this industry, and that is men market segmentation. Data from Future Market Insights in 2019 reports that by 2018, globally, men worldwide have spent US\$ 9.5 billion on skincare products, and in the following year it has increased by $8 \%$. This trend was predicted to increase and reach up to 10 times by the year 2024 based on this year market research by Statista Consumer Market Outlook.

On a national scale, there is data from the survey by the year 2003, called Future of Men, Study in Indonesia, which shows that at least $36.67 \%$ of Indonesian men spent up to 5 million Rupiah per month for grooming and body care needs (MarkPlus \& Co., 2003). Even the beauty category is on the top 3 e-commerce spend by category (Datareportal, 2019). In Indonesia, most social media users to consumers who shop on e-commerce are men (Datareportal, 2019). Again, this shows a positive trend, and that male segmentation is a fast-growing market, including beauty industry. Also, surprisingly, men are the most active markets on the internet nowadays in this country.

This then becomes more interesting considering that the market for men's skincare products in Indonesia is still relatively deserted even though good opportunities are starting to appear, and those could even lead to become growing factor of the beauty industry in Indonesia. This research aims to explore factors associated with the men's attitude and intention towards skincare products. With the help of this study, hopefully people can understand more about men's market and their buying behavior.

\section{THEORETICA BACKGROUND AND L HYPOTHESES}

Before discussing the factors and variables studied in this paper, buying decisions and attitudes are two major theories that underlie this research. This is based on the basic assumption that a positive attitude leads to 
buying decisions, as buying decisions themselves are the main goal for marketers in selling their products.

From the researcher's review, there are many variables that can be considered and are likely to influence attitudes and intentions of male consumers in consuming skincare. A wide range of research variables delivered in this paper. There are three dimensions, which are personal factors, socio-cultural factors, and marketing factors. Personal factors concern men's selfimage congruity, ageing effect, physical attractiveness, and healthcare. Socio-cultural factors concern men's social beliefs and lifestyle. And the last, marketing factors, concerns about social media advertising, celebrity endorsement, online purchase situation, and price value.

\section{Personal Factors}

\section{Self-image Congruity}

Consumption is a part of creating self-identity process (Kellner, 1992). In 1999, Aaker states that, it is when individual person decided to buy, use, or consume a product, they tend to choose product or brand that represents and connects with their self-image aspect (Solomon, 2013). The process of forming self-image congruity, includes many factors such as physical, psychological, and social, which are also influenced by the attitudes, habits, beliefs, and ideas of the individual (Souiden \& Diagne, 2009).

For those reason, beauty such as skincare products are existed to provide a significant role in supporting the process and formation of the self-image concept of someone, both real and ideal self-image. Based on the previous discussion, the following hypothesis is generated

H1. Self-image congruity positively influences the attitude of male consumer towards skincare products

\section{Aging Effect.}

Aging comes with a lot of significant changes, from physical performance, skin condition, mental to social life. Therefore, there are several studies that state that the main motivation for male consumers to buy skincare products is the aging factor (Sturrock \& Pioch, 1998). In a men's world, good opportunities in this real life, such as careers, are more available to those who are young, it is no wonder that, young men are also starting to look at anti-aging products and other cosmetics to prevent aging effect (Sturrock \& Pioch, 1998; Sarpila \& Rasanen, 2011; Khan et., al, 2017). The importance and relevance of aging factors in the use of skincare products make this variable need to be included in this research. Based on the previous discussion, the following hypothesis is generated.
H2. Aging effect positively influences the attitude of male consumer towards skincare products

\section{Physical Attractiveness}

Several studies have shown that personal development and career success is influenced by good physical factors, from the face, skin, body shape, to body weight (Sarlio-Lahteenkorva, Silventoinen \& Lahelma, 2004; Harkonen, 2007). The hope of getting an attractive physical appearance is the main reason of the use of skincare products. One of the reasons why men are paying more attention to their physical appearance is the pressure of existing social interactions and challenges that occur in their daily lives (Grogan, 1999; Souiden \& Diagne, 2009). This then supports the context of this research to use the urban male as the object of this study. Based on the previous discussion, the following hypothesis is generated.

H3. Physical attractiveness positively influences the attitude of male consumer towards skincare products

\section{Healthcare}

Expectations for skin health are driving consumer attitudes in using skincare products. Attention to health positively affects the attitudes of Indonesian male consumers in using skin care products (Irawan and Widjaja, 2017). And in fact, men's skin is more susceptible to damage by UV rays, environmental pollution and other factors that cause more wrinkles and hyperpigmentation on the skin (Khuong \& Duyen, 2016). Based on the previous discussion, the following hypothesis is generated.

H4. Healthcare positively influences the attitude of male consumer toward skincare products

\section{Socio-cultural Factors}

\section{Social Beliefs}

A person's belief in the assessment of their environment is a supporting factor for consumer attitudes in using skincare products. Cosmetics can affect a person's feeling because of their ability to improve one's appearance. One of the stimuli for the consumption of male care products is for the formation, development, and care that lead to the male self-image (Irawan and Widjaja, 2017). Social expectations have a major influence on male consumer behavior in buying male facial skin care products, because of the pressure of the surrounding environment and the desire to always look perfect in front of others, which encourages consumers to buy facial skin care products (Wijaya, 2018). Based on the previous discussion, the following hypothesis is generated.

H5. Social Beliefs positively influences the attitude of male consumer toward skincare products 


\section{Lifestyle}

Lifestyle affects consumer attitudes in using skincare products. There is research from Bulan, Rizal and Akbar (2019), which says that lifestyle shows a positive influence on buying decisions, in other words, if the lifestyle increases by one unit, buying decisions will also increase (Alalwan, 2018). The development of times and technology, the use of the internet, smartphones, applications, and other gadgets make the interactions that occur in society also change. Today's consumer needs have led to a lifestyle that requires consumers to make choices for goods or services that suit their needs. Lifestyle is a part of consumer behavior that affects consumer action in making a purchase (Purnamasari, Hidayat, and Widiartanto, 2017). Lifestyle is related to segmentation. Companies must realize that it is impossible to serve all consumers in the market. A lifestyle shows the pattern of life of the person concerned which is reflected in the activities, interests and income. A person's lifestyle shows the pattern of the person's life which is reflected in their activities, interests and opinions. So, it it makes a deep sense that, urban men, are more likely to use beauty products such as skincare than those who live in rural areas (Liu, 2006). Based on the previous discussion, the following hypothesis is generated.

H6. Lifestyle positively influences the attitude of male consumer toward skincare products

\section{Marketing Factors}

\section{Social Media Advertising}

Social media advertising currently has a role in influencing consumer attitudes in making purchases. According to Tuten and Solomon (2017), social media is used as a promotional and communication tool with the aim of directing consumers to the decision-making process. Social media has become a part of every individual's life. Anything can be done through social media, including advertising activities. Various platforms are now increasingly dividing their user segmentation so that it has impact on marketers and brands when they want to find and reach their target market. Most practitioners and researchers Alalwan, Dwivedi, Rana, \& Williams, 2016; Alalwan et al, 2017; Braojos-Gomez et al, 2015; Duffet, 2015; Jung, Shim, Jin, \& Khang, 2016; Kamboj et al, 2018; Shareef et al, 2017; Shareef, Mukerji, Alryalat, Wright, \& Dwivedi, 2018; Zhu \& Chang, 2016) found that the main interest that brands have on social media is to advertise (Alalwan, 2018). According to Tuten and Solomon (2017), social media is used as a promotional and communication tool with the aim of directing consumers to the decision-making process. According to (Shareef et al, 2019), advertisements carried out on social media such as Facebook have a significant role in increasing the value of advertising in the minds of customers, so that a positive image is formed through the attitudes of customers who are interested in these products. (Alalwan, 2018). For this reason, advertising on social media is important in influencing male consumers to buy skincare products. Based on the previous discussion, the following hypothesis is generated.

H7. Social media advertising positively influences the attitude of male consumer toward skincare products

\section{Celebrity Endorsement}

Celebrity endorsers are currently used by advertisers to influence consumer attitudes in making purchase decisions. Celebrity endorsers for facial care products can shape consumer attitudes ranging from cognitive, affective, and conative attitudes. Attitude is one of the crucial factors that will influence purchasing decisions. Consumers who are interested in the results displayed by advertisements and advertisement stars to plans to buy and use skincare products are things that strengthen the influence of the research results. (Mulyawati, Kumadji, and Kusumawati, 2015). Source credibility is the thing that most influences attitude. Celebrity endorsement can have an impact on a consumer's evaluation memory, attention, and purchase interest, however, even if consumers have a favorable disposition towards the celebrity, this does not necessarily translate into purchase intention. (Muthohar and Triatmaja, 2017). Agnes Monica as Oil of Olay's advertising ambassador is only on a moderate level. There is no feature that respondents feel about this figure. In general, the respondents have the belief that whitening soap advertisements have moderate effectiveness. (Legasari, Indarti and Restuti, 2016). Celebrity endorsers have a noteworthy influence on male consumer behavior in buying male facial skin care products, because the use of celebrities who are idols in promoting products will buy these products by their idols (Prisilia Wijaya, 2018). Based on the previous discussion, the following hypothesis is generated H8. Celebrity endorsement positively influences the attitude of male consumer toward skincare products

\section{Online Purchase Situations}

The rise of online shopping sites makes it easier for consumers to find the desired product and easily learn the core benefits of these products. Several previous studies on the influence of online shopping sites in influencing consumer attitudes: from the discussion, it can be concluded that the decision-forming factor 
(behavior) is interest (intention) and the factors forming the intention are one of which is the attitude of consumers and consumer attitudes are dominant. large percentages are perceived ease of use, perceived usefulness, and perceived risk (Sulaeman, 2018). The three perceptions above are the results of respondents who stated that it is important for their perceptions of an e-commerce so that they can interest and buy there. Because products in one e-commerce are the same as the same brand and product specifications, this comparison is what makes consumers decide to use ecommerce as their shopping place. Male consumers tend to shop if they can easily get information about the items to be bought (Banyte, Rutelione, Jaruseviciute, 2015). This characteristic can be found in online or online shopping situations. Plus, many people, especially urban people, are now using gadgets as a means of daily communication. Those in urban areas have faster activity dynamics than other areas. So that everything that can be accessed anytime, anywhere, will be very preferable as the first choice. On the other hand, Indonesia is the country with the first e-commerce growth in the world, proving that the online shopping situation is an aspect that has a positive effect on consumers for products or brands (idEA, 2018). This shows that buying through an online shop can influence male consumers' attitudes towards the decision to buy skincare products. Based on the previous discussion, the following hypothesis is generated

H9. Online Purchase Situation positively influences the attitude of male consumer toward skincare products

\section{Price Value}

Price has a vital role in determining the attitude of consumers to buy a product, the suitability of price with the benefits obtained becomes the basis for the perception of price compatibility with the value of the item. Based on the results of previous research as follows: from the results of the analysis, it was found that the price variable had a significant effect on consumer attitudes of Pond's cosmetic products. This can be used as an excuse in perceiving the suitability of price with the quality obtained from skincare, because price value compatibility is the result of consumers' perceptions of comparing prices with benefits obtained (Fitriani, Ramayani, and Areva, 2018). Price perceptions affect the attitudes of male consumers in assessing price suitability with the quality of skincare products, by considering indicators of price suitability with product quality, price compatibility with benefits and competitive prices, it is expected that the company can provide prices that match these indicator criteria. Because price perceptions influence consumer buying decisions for skincare products (Cahyani, 2017). Price perception is formed by four indicators, namely: price affordability, price suitability with product quality, price competitiveness, and price compatibility with benefits in influencing consumer attitudes (Winahayu, 2017). Based on the previous discussion, the following hypothesis is generated H1O. Price Value positively influences the attitude of male consumer toward skincare products

\section{Attitude}

Consumer attitudes have a positive influence on buying decision variables. Consumer attitude variables with indicators of cognitive, affective, and conative attitudes influence consumer decisions to buy skincare products. In this case, attitudes form perceptions of what consumers will buy, attitudes show an assessment of the appropriateness of the value with the benefits contained in a product, so that it can affect consumer buying decisions (Mulyawati, Kumadji, and Kusumawati, 2015). Attitudes also greatly affect a person's behavior, in which there is a person's behavior or actions, perceptions and the way of thinking of a person who feels that what he has done will be related to a situation and the values that are in him. Attitudes also greatly affect the motivating power of a person to motivate others around him. So that in this case it can also lead to a fairly pleasant experience (Kelana, 2019). Consumer attitudes have a major influence on male consumer behavior in buying male facial skin care products, this is due to a stronger inner drive to look perfect so that they will not be influenced by those closest to them, regardless of whether they use or do not use the product (Wijaya, 2018).

H11. Attitude positively influences the behavioral intentions of male consumer toward skincare products 


\section{Behavioral Intention}

\section{Repurchase Intention}

According to Ndubisi and Moi (2005), re-buying varies depending on the level of durability of a product, for a product that does not have long durability, then repurchase is defined as the act of buying back after making the first or trial purchase. Meanwhile, durable products are defined as the desire of consumers to make repeat purchases or provide suggestions to others to make purchases.

Meanwhile, according to Engel, Blackwell and Miniard (2001), specific re-purchase is a form of purchase intention that describes the expectation to make repeat purchases. Hellier et al (2003) argue that repurchase intention is a person's planned decision to repurchase certain services with consideration of the situation and level of interest in the product. Based on these reference journals, a conceptual model that can influence the attitudes and interests of consumers in consuming cosmetic products is obtained which is influenced by personal factors, social culture, and marketing factors with a model like the following:

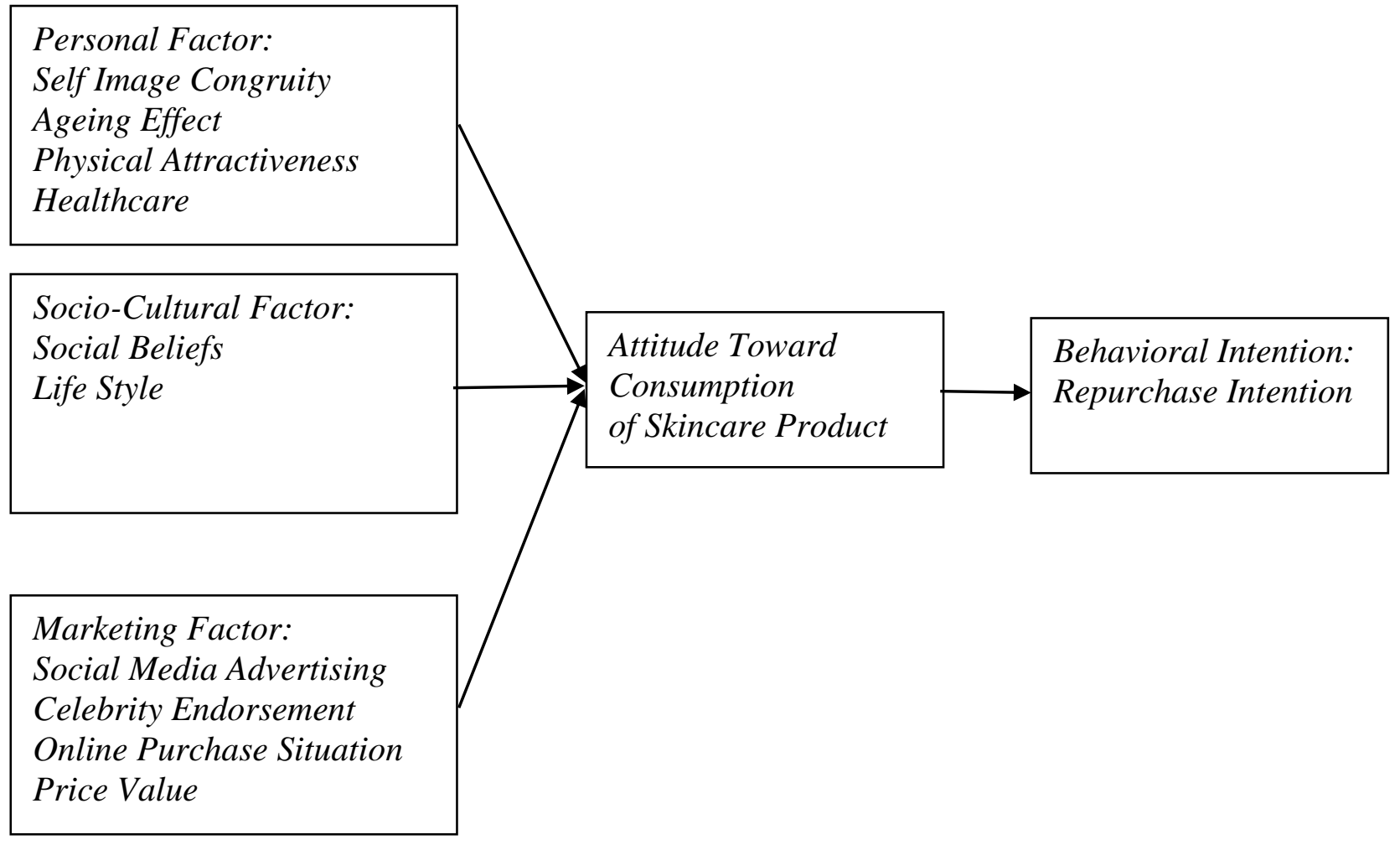

Figure 1. Conceptual Research Model

\section{RESEARCH METHODOLOGY}

\section{Questionnaire}

The questionnaire consists of 3 parts. The first is a screening question of basic information from respondents, such as age, occupation, status, and skincare products that have been bought, as well as the frequency of buying skincare products. In the second part, respondents will be asked questions according to the needs of the existing research variables. In this section, there are 12 variables to be measured in this research. Self-image congruity was measured by four indicators which were extracted from Sukato and Elsey (2009), Cheng, Ooi, and Ting (2010), and Sirgy, et., al (1997). Ageing effect was measured by three indicators which all three were extracted from Sturrock (1998).
Physical attractiveness was measured by four indicators which were extracted, two items from Marthur, et., al (2010) and two items from Thohir (2015). Healthcare was measured by four indicators which two were extracted from Sturrock (1998) and the other two were from Shih and Fang (2004). Social belief was measured by three indicators which were extracted from Sweeney and Sweeney (2001) and Sontag and Lee (2004). Lifestyle was measured by seven indicators which were extracted from Harcar and Kaynak (2008), Kharisma (2016), Setitit (2017), Oktavianto (2017), Amback et., al (2019) and Rahmah, Sumarwan, and Najib (2015). Social Media Advertising was measured by four indicators which were extracted from Taylor, Lewin, 
and Strutton (2011), Rahman and Rashid (2018), and Daroch (2017). Celebrity endorsement was measured by three indicators which were extracted from Esangbedo, R., (2011), Cheng, Ooi, and Ting (2010), and Rabia et., al (2019). Online purchase situation was measured by six indicators which were extracted from Wang and Emurian (2005), Lee, Ibrahim, and Hsueh-Shan (2005), and Shergill and Chen (2005). Price value was measured by three indicators which were extracted from Ahtola (1984), Zeithaml (1988), and Sweeney and Soutar (2001). Attitude was measured by three indicators which were extracted from Tarkiainen and Sundqvist (2005), Thogersen (2007), and Aertsens et., al (2009). And the last variable is behavioral intention was measured by five indicators which were extracted from Schiffman et., al (2008), Wang et., al (2013), Rivai, Berry, and Parasuraman (1996). And finally, in the last section has demographic data from respondents. Variables such as age, occupation, marital status and monthly expense were considered.

\section{Sample}

The target population of this study were male respondents with age over 17 years old, who live in DKI Jakarta and have used skincare products in the last 1-2 months. The choice of male respondents age over 17 years old refers to the main requirement of age for ownership of a citizen identity card in Indonesia. DKI Jakarta known as the capital city and the center of administration and business, was chosen for this research as a great representative of the urban area. After determining the right target population, we selected sampling techniques, namely nonprobability using snowball and convenience sampling. With the snowball method, researcher uses one to several known samples to reach other samples. And then the convenience method is chosen with the consideration that it will be easier to get random samples (Dornyei, 2007. Determining the number of sample respondents refers to Supranoto (2001) which says that a good sample size can be figured out by multiplying the number of questionnaire questions by five, so that the minimum number of respondents required is 49 items $\mathrm{x}$ $5=245$ respondents. The total sample obtained was 384 respondents.

\section{DATA ANALYSIS AND DISCUSSION}

Tabel 1. Validity and Reliability Test

\begin{tabular}{|c|c|c|c|c|c|c|}
\hline Variable & Item & $\lambda$ & $\lambda_{2}$ & e & CR & VE \\
\hline \multirow{4}{*}{ SIC } & SIC1 & 0,72 & 0,52 & 0,48 & \multirow{4}{*}{0,89} & \multirow{4}{*}{0,66} \\
\hline & SIC2 & 0,83 & 0,69 & 0,31 & & \\
\hline & SIC3 & 0,87 & 0,76 & 0,24 & & \\
\hline & SIC4 & 0,82 & 0,67 & 0,33 & & \\
\hline \multirow{3}{*}{ AGE } & AGE1 & 0,88 & 0,77 & 0,23 & \multirow{3}{*}{0,91} & \multirow{3}{*}{0,78} \\
\hline & AGE2 & 0,93 & 0,86 & 0,14 & & \\
\hline & AGE3 & 0,83 & 0,69 & 0,31 & & \\
\hline \multirow{4}{*}{ PA } & PA1 & 0,91 & 0,83 & 0,17 & \multirow{4}{*}{0,91} & \multirow{4}{*}{0,72} \\
\hline & PA2 & 0,89 & 0,79 & 0,21 & & \\
\hline & PA3 & 0,76 & 0,58 & 0,42 & & \\
\hline & PA4 & 0,82 & 0,67 & 0,33 & & \\
\hline \multirow{4}{*}{$\mathrm{HC}$} & $\mathrm{HC1}$ & 0,80 & 0,64 & 0,36 & \multirow{4}{*}{0,86} & \multirow{4}{*}{0,61} \\
\hline & $\mathrm{HC} 2$ & 0,84 & 0,71 & 0,29 & & \\
\hline & $\mathrm{HC} 3$ & 0,70 & 0,49 & 0,51 & & \\
\hline & $\mathrm{HC} 4$ & 0,79 & 0,62 & 0,38 & & \\
\hline \multirow{3}{*}{ SB } & SB1 & 0,91 & 0,83 & 0,17 & \multirow{3}{*}{0,90} & \multirow{3}{*}{0,75} \\
\hline & SB2 & 0,88 & 0,77 & 0,23 & & \\
\hline & SB3 & 0,80 & 0,64 & 0,36 & & \\
\hline \multirow[t]{4}{*}{ LS } & LS1 & 0,66 & 0,44 & 0,56 & \multirow[t]{4}{*}{0,90} & \multirow[t]{4}{*}{0,57} \\
\hline & LS2 & 0,78 & 0,61 & 0,39 & & \\
\hline & LS3 & 0,82 & 0,67 & 0,33 & & \\
\hline & LS4 & 0,71 & 0,50 & 0,50 & & \\
\hline
\end{tabular}




\begin{tabular}{|c|c|c|c|c|c|c|}
\hline Variable & Item & $\lambda$ & $\lambda_{2}$ & e & CR & VE \\
\hline & LS5 & 0,72 & 0,52 & 0,48 & & \\
\hline & LS6 & 0,78 & 0,61 & 0,39 & & \\
\hline & LS7 & 0,79 & 0,62 & 0,38 & & \\
\hline \multirow{4}{*}{ SMA } & SMA1 & 0,75 & 0,56 & 0,44 & \multirow{4}{*}{0,91} & \multirow{4}{*}{0,73} \\
\hline & SMA2 & 0,86 & 0,74 & 0,26 & & \\
\hline & SMA3 & 0,92 & 0,85 & 0,15 & & \\
\hline & SMA4 & 0,87 & 0,76 & 0,24 & & \\
\hline \multirow{3}{*}{$\mathrm{CE}$} & CE1 & 0,92 & 0,85 & 0,15 & \multirow{3}{*}{0,95} & \multirow{3}{*}{0,85} \\
\hline & CE2 & 0,90 & 0,81 & 0,19 & & \\
\hline & CE3 & 0,95 & 0,90 & 0,10 & & \\
\hline \multirow[t]{6}{*}{ OPS } & OPS1 & 0,75 & 0,56 & 0,44 & \multirow[t]{6}{*}{0,92} & \multirow[t]{6}{*}{0,65} \\
\hline & OPS2 & 0,79 & 0,62 & 0,38 & & \\
\hline & OPS3 & 0,84 & 0,71 & 0,29 & & \\
\hline & OPS4 & 0,82 & 0,67 & 0,33 & & \\
\hline & OPS5 & 0,83 & 0,69 & 0,31 & & \\
\hline & OPS6 & 0,79 & 0,62 & 0,38 & & \\
\hline \multirow{3}{*}{ PV } & PV1 & 0,70 & 0,49 & 0,51 & \multirow{3}{*}{0,84} & \multirow{3}{*}{0,65} \\
\hline & PV2 & 0,95 & 0,90 & 0,10 & & \\
\hline & PV3 & 0,74 & 0,55 & 0,45 & & \\
\hline \multirow{3}{*}{ AT } & AT1 & 0,91 & 0,83 & 0,17 & \multirow{3}{*}{0,97} & \multirow{3}{*}{0,91} \\
\hline & AT2 & 0,97 & 0,94 & 0,06 & & \\
\hline & AT3 & 0,98 & 0,96 & 0,04 & & \\
\hline \multirow[t]{3}{*}{ BI } & BI1 & 0,73 & 0,53 & 0,47 & \multirow[t]{3}{*}{0,86} & \multirow[t]{3}{*}{0,55} \\
\hline & BI2 & 0,68 & 0,46 & 0,54 & & \\
\hline & BI3 & 0,81 & 0,66 & 0,34 & & \\
\hline
\end{tabular}

construct is reliable. Based on the Table 1 above, all indicators of the variables studied had a loading factor value greater than 0.5 , also a $C R$ value greater than 0.7 and VE value greater than 0.5 , so it was concluded that all the variables studied were valid and reliable.

Table 2. Respondent Demographics

\begin{tabular}{|c|c|c|c|c|}
\hline No. & $\begin{array}{l}\text { Respondent } \\
\text { Demographi } \\
\text { cs }\end{array}$ & Category & $\begin{array}{c}\text { Freque } \\
\text { ncy }\end{array}$ & $\begin{array}{c}\text { Percentag } \\
\text { e (\%) }\end{array}$ \\
\hline \multirow{4}{*}{1} & \multirow{4}{*}{ Age } & $20-29$ & 301 & 78,39 \\
\hline & & $30-39$ & 69 & 17,97 \\
\hline & & $40-49$ & 12 & 3,13 \\
\hline & & $\begin{array}{c}>50 \text { years } \\
\text { old }\end{array}$ & 2 & 0,52 \\
\hline \multirow{5}{*}{2} & \multirow{5}{*}{ Job } & Employee & 115 & 29,9 \\
\hline & & $\begin{array}{c}\text { Entrepren } \\
\text { eur }\end{array}$ & 106 & 27,6 \\
\hline & & $\begin{array}{c}\text { Governme } \\
\text { nt } \\
\text { employee }\end{array}$ & 85 & 22,1 \\
\hline & & $\begin{array}{c}\text { Mahasisw } \\
\text { a }\end{array}$ & 68 & 17,7 \\
\hline & & etc. & 10 & 2,7 \\
\hline \multirow{3}{*}{3} & \multirow{3}{*}{$\begin{array}{l}\text { Marital } \\
\text { Status }\end{array}$} & Single & 246 & 64,1 \\
\hline & & Married & 135 & 35,2 \\
\hline & & Divorce & 3 & 0,7 \\
\hline \multirow[b]{2}{*}{4} & \multirow{2}{*}{$\begin{array}{l}\text { Expense per } \\
\text { Month }\end{array}$} & $\begin{array}{c}<\mathrm{Rp} \\
1.500 .000\end{array}$ & 76 & 19,8 \\
\hline & & $\begin{array}{c}\mathrm{Rp} \\
1.500 .000 \\
-\mathrm{Rp}\end{array}$ & 137 & 35,7 \\
\hline
\end{tabular}

\begin{tabular}{|c|l|c|c|c|c|c|}
\hline Variable & Item & $\boldsymbol{\lambda}$ & $\boldsymbol{\lambda}^{\mathbf{2}}$ & $\mathbf{e}$ & $\mathbf{C R}$ & $\mathbf{V E}$ \\
\hline & $\mathrm{BI} 4$ & 0,78 & 0,61 & 0,39 & & \\
\cline { 2 - 6 } & BI5 & 0,69 & 0,48 & 0,52 & & \\
\hline
\end{tabular}

An evaluation of the measurement model is carried out through the Confirmatory Factor Analysis by testing the validity and reliability of the constructs. The validity of the construct is tested by looking at the loading factor value, if the loading factor is greater than 0.5 then the indicator is declared valid. Meanwhile, the reliability test was carried out by looking at the value of Construct Reliability and Variance Extracted in each construct. If the $\mathrm{CR}$ value is $\geq 0.7$ and $\mathrm{VE} \geq 0.5$, it means that the

\begin{tabular}{|c|c|c|c|c|}
\hline No. & $\begin{array}{l}\text { Respondent } \\
\text { Demographi } \\
\text { cs }\end{array}$ & Category & $\begin{array}{c}\text { Freque } \\
\text { ncy }\end{array}$ & $\begin{array}{c}\text { Percentag } \\
\text { e }(\%)\end{array}$ \\
\hline & & 3.000 .000 & & \\
\hline & & $\begin{array}{c}\mathrm{Rp} \\
3.000 .000 \\
-\mathrm{Rp} \\
6.000 .000\end{array}$ & 101 & 26,3 \\
\hline & & $\begin{array}{c}\mathrm{Rp} \\
6.000 .000 \\
-\mathrm{Rp} \\
9.000 .000\end{array}$ & 47 & 12,2 \\
\hline & & $\begin{array}{c}>\mathrm{Rp} \\
9.000 .000\end{array}$ & 23 & 6,0 \\
\hline
\end{tabular}


Based on the table 2 above, from total of 384 male respondents, the majority 301 respondents or $78.39 \%$, came from the age range from 20 to 29 years old. Then based on the characteristics of employment, the majority came from the employees with total 115 respondents or $29.9 \%$, only $2 \%$ difference from the self-employed job category which is 106 respondents or $27.6 \%$. For the category of marital status, namely single, married, and divorced, the majority came from respondents with single status, which is 246 respondents or $64.1 \%$. And the last data relates to monthly expenses, spending on mortgage and vehicle installments excluded, the purpose is to see the level of consumption of male respondents. From total of 384 respondents, the majority with total 137 respondents, have an expense of Rp. 1,500,000 - Rp. $3,000,000$ per month.

Table 3. Hypothesis Test Result

\begin{tabular}{|c|c|c|c|c|c|}
\hline $\begin{array}{l}\text { Hyp } \\
\text { othes } \\
\text { is }\end{array}$ & Path & $\begin{array}{c}T- \\
\text { Value }\end{array}$ & $\begin{array}{c}\text { Estimat } \\
\mathrm{e}\end{array}$ & Statement & Result \\
\hline H1 & $\begin{array}{l}\text { Self- } \\
\text { Image } \\
\text { Congrui } \\
\text { ty } \rightarrow \\
\text { Attitude }\end{array}$ & 2,45 & 0,12 & $\begin{array}{l}\text { Self-Image } \\
\text { Congruity } \\
\text { positively } \\
\text { effect } \\
\text { Attitude }\end{array}$ & Accepted \\
\hline $\mathrm{H} 2$ & $\begin{array}{l}\text { Aging } \\
\text { Effect } \\
\rightarrow \\
\text { Attitude }\end{array}$ & 2,58 & 0,13 & $\begin{array}{l}\text { Aging Effect } \\
\text { positively } \\
\text { effect } \\
\text { Attitude }\end{array}$ & Accepted \\
\hline H3 & $\begin{array}{l}\text { Physica } \\
l \\
\text { Attracti } \\
\text { veness } \\
\rightarrow \\
\text { Attitude }\end{array}$ & 2,68 & 0,16 & $\begin{array}{l}\text { Physical } \\
\text { Attractivene } \\
\text { ss positively } \\
\text { effect } \\
\text { Attitude }\end{array}$ & Accepted \\
\hline H4 & $\begin{array}{l}\text { Healthc } \\
\text { are } \rightarrow \\
\text { Attitude }\end{array}$ & 4,81 & 0,28 & $\begin{array}{l}\text { Healthcare } \\
\text { positively } \\
\text { effect } \\
\text { Attitude }\end{array}$ & Accepted \\
\hline $\mathrm{H} 5$ & Social & 2,74 & 0,12 & Social & Accepted \\
\hline
\end{tabular}

\begin{tabular}{|c|c|c|c|c|c|}
\hline $\begin{array}{l}\text { Hyp } \\
\text { othes } \\
\text { is }\end{array}$ & Path & $\begin{array}{c}T- \\
\text { Value }\end{array}$ & $\begin{array}{c}\text { Estimat } \\
\mathrm{e}\end{array}$ & Statement & Result \\
\hline & $\begin{array}{l}\text { Beliefs } \\
\rightarrow \\
\text { Attitude }\end{array}$ & & & $\begin{array}{l}\text { Beliefs } \\
\text { positively } \\
\text { effect } \\
\text { Attitude }\end{array}$ & \\
\hline H6 & $\begin{array}{l}\text { Lifestyle } \\
\rightarrow \\
\text { Attitude }\end{array}$ & 2,05 & 0,10 & $\begin{array}{l}\text { Lifestyle } \\
\text { positively } \\
\text { effect } \\
\text { Attitude }\end{array}$ & Accepted \\
\hline $\mathrm{H} 7$ & $\begin{array}{l}\text { Social } \\
\text { media } \\
\text { advertis } \\
\text { ing } \rightarrow \\
\text { Attitude }\end{array}$ & 1,97 & 0,05 & $\begin{array}{l}\text { Social media } \\
\text { advertising } \\
\text { positively } \\
\text { effect } \\
\text { Attitude }\end{array}$ & Accepted \\
\hline $\mathrm{H} 8$ & $\begin{array}{l}\text { Celebrit } \\
y \\
\text { Endorse } \\
\text { ment } \rightarrow \\
\text { Attitude }\end{array}$ & 0,42 & 0,02 & $\begin{array}{l}\text { Celebrity } \\
\text { Endorsemen } \\
t \text { has no } \\
\text { effect on } \\
\text { Attitude }\end{array}$ & Rejected \\
\hline H9 & $\begin{array}{l}\text { Online } \\
\text { Purchas } \\
e \\
\text { Situatio } \\
n \rightarrow \\
\text { Attitude }\end{array}$ & 0,35 & 0,02 & $\begin{array}{l}\text { Online } \\
\text { Purchase } \\
\text { Situation } \\
\text { has no effect } \\
\text { on Attitude }\end{array}$ & Rejected \\
\hline $\mathrm{H} 10$ & $\begin{array}{l}\text { Price } \\
\text { Value } \\
\rightarrow \\
\text { Attitude }\end{array}$ & 2,46 & 0,13 & $\begin{array}{l}\text { Price Value } \\
\text { positively } \\
\text { effect } \\
\text { Attitude }\end{array}$ & Accepted \\
\hline H11 & $\begin{array}{l}\text { Attitude } \\
\rightarrow \\
\text { Behavio } \\
\text { ral } \\
\text { Intentio } \\
\text { ns }\end{array}$ & 10,83 & 0,66 & $\begin{array}{l}\text { Attitude } \\
\text { positively } \\
\text { effect } \\
\text { Behavioral } \\
\text { Intentions }\end{array}$ & Accepted \\
\hline
\end{tabular}

On the relationship between (SIC) Self-image Congruity and (AT) Attitude, the t-value is 2.45 which is greater than the t-table value (1.96). This result indicates that the Self-image Congruity variable positively has significant effect (5\% significant level) on the Attitude variable. Then the estimated coefficient value is 0.12 . So, it can be concluded that self-image congruity positively affects the attitude of male consumers towards skincare products. These results are in line with previous research from Solomon (2017), which states that a person's perception of himself creates a tendency to buy products that resonate with their self-image. These results are also the same as the previous findings of Souiden and Diagne (2009), on Canadian men in the consumption of personal care products. From the results, it is evident that urban male consumers realize the importance of using skincare products as a support for congruence between existing self-image and the ideal image to be achieved. 
On the relationship between (AGE) Ageing Effect and (AT) Attitude, the t-value is 2.58 , which is greater than $\mathrm{t}$-table value (1.96). This result indicates that the Ageing Effect variable positively affects the Attitude variable. Then the estimated coefficient value is 0.13 . So, it can be concluded that the aging effect felt by male consumers positively affects their attitude towards skincare products. This is in line with previous research which states that aging factors have a major influence on men's attitudes towards the use of cosmetic and skincare products (Sturrock \& Pioch, 1998; Souiden \& Diagne, 2009; Sarpila \& Rasanen, 2011).

On the relationship between (PA) Physical Attractiveness and (AT) Attitude, the t-value is 2.68, which is greater than t-table value (1.96). This result indicates that the Physical Attractiveness variable has a significant effect on the Attitude variable. Therefore, it can be concluded that for male consumers, physical attractiveness positively affects their attitudes towards consuming skincare products. This result is in line with previous research by Souiden and Diagne (2009). This also supports research from Grogan (1999), which states that increased attention to physical appearance by men is a response to the social pressure they go through, in accordance with the research context, which is urban men.

On the relationship between (HC) Healthcare and (AT) Attitude, the t-value is 4.81 , which is greater than the $\mathrm{t}$ table value (1.96), this result indicates that the Healthcare variable has a statistically significant effect on the Attitude variable. Then the estimated coefficient value is 0.28 . Therefore, it can be concluded that for male consumers, the need to maintain health positively affects their attitude towards skincare products. This result is in line with previous research (Souiden \& Diagne, 2009; Irawan \& Widjaja, 2017). These results are proven to support research on the importance of using skincare products for men, since men's skin is also generally susceptible to UV damage and pollution (Khuong \& Duyen, 2016).

On the relationship between (SB) Social Beliefs and (AT) Attitude, the t-value is 2.74 , which is greater than the $\mathrm{t}$-table value (1.96), this result indicates that the Social Beliefs variable has a statistically significant effect on the Attitude variable. The estimated coefficients value is 0.14 . Therefore, it can be concluded that for male consumers, the social beliefs that exist in their environment, positively affect their attitudes towards skincare products. This result also in line with the findings in previous studies which state that culture and social beliefs have an influence on consumer behavior because cultural components that contain beliefs can directly influence and even dictate individual behaviors (Weber \& de Ville Bonne, 2002; Souiden \& Diagne, 2009).

On the relationship between (LS) Lifestyle and (AT) Attitude, the $\mathrm{t}$-value is 2.05 , which is greater than the $\mathrm{t}$ table value (1.96), this result indicates that the Lifestyle variable has a statistically significant effect on the Attitude variable. The estimated coefficient value is 0.10 . Therefore, it can be concluded that for male consumers, lifestyle factors positively affect their attitudes toward consuming skincare products. This study proves that Liu's (2006) previous research, which states that urban men use beauty and personal cares products more than those who live in rural areas.

On the relationship between (SMA) Social Media Advertising and (AT) Attitude, the t-value is 1.97, which is greater than the $t$-table value (1.96), this result indicates that the Social Media Advertising variable has statistically significant effect on the Attitude variable. The estimated coefficient value is 0.092 . Therefore, it can be concluded that for male consumers, advertisements displayed on social media positively affect their attitudes towards skincare products. This finding is in line with the results of research from Tuten and Solomon (2017), which state that social media is used as a means of promotion and communication with the aim of directing consumers to the decision-making process.

On the relationship between (CE) Celebrity Endorsement and (AT) Attitude, the t-value is 0.42, which is smaller than the t-table value (1.96), this result indicates that the variable Celebrity Endorsement does not positively affect the Attitude variable. The estimated coefficient value is 0.017. Therefore, it can be concluded that for male consumers, the role of celebrities in marketing skincare products does not have a positive influence on their attitudes. This means that there is a failure and ineffective use of celebrity figures in targeting male consumers in the skincare product sector. This study does not support the research from Dwivedi, Johnson, and McDonald (2015), which states that celebrity endorsement is one of the most effective marketing tools in increasing brand equity. However, there are other aspects that can be considered as reasons for the failure to use celebrities so far, such as credibility and the relationship between celebrity 
personalities and brands (Dwivedi, Johnson, McDonald, 2015).

On the relationship between (OPS) Online Purchase Situation and (AT) Attitude, the t-value is 0.35 , which is smaller than the t-table value (1.96), this result indicates that the Online Purchase Situation variable does not have a statistically significant effect on the Attitude variable. The estimated coefficient value is 0.017 . Therefore, it can be concluded that, for male consumers, online shopping situations, such as e-commerce, do not have a significant positive effect on their attitudes in buying skincare products. The results of this study support the findings of Souiden and Diagne (2009), which state that Parisian men are more confident about shopping for cosmetic or other personal care products through offline store. Research from Banyte et., Al (2015), also supports this result, where there are aspects of direct communication and consultation in stores, which male consumer consider to be very helpful for them in deciding to purchase certain products, for example, skincare products.

On the relationship between (PV) Price Value and (AT) Attitude, the t-value is 2.46 , which is greater than $\mathrm{t}$ table value (1.96), this result indicates that the Price Value variable has a statistically significant effect on the Attitude variable. The estimated coefficient value is 0.13 . Therefore, it can be concluded that for male consumers, the price factor positively affects their attitude in buying skincare products. This finding is in line with previous research, thus proving that male consumers are a market segmentation that is quite sensitive to price (Antoinette, 2009; Surakiat Pinyo, 2010).

On the relationship between (AT) Attitude and (BI) Behavioral Intentions, the t-value is 10.83 , which is greater than the t-table value (1.96), this result indicates that the Attitude variable has a statistically significant effect on the Behavioral Intention variable. The estimated coefficient value is 0.66 . Therefore, it can be concluded that for male consumers, a positive attitude is formed from each exogenous variable in the existing research dimensions that have a positive effect on the intention of the men's consumption behavior. This finding is in line with previous studies (Ajzen \& Fishbein, 2000; Akurtan \& Tezacan, 2012, Kelana, 2019).

\section{THEORETICAL AND MANAGERIAL IMPLICATION}

This study contributes to the literature on understanding male market behavior especially in cosmetic and/or beauty industry in Indonesia. Findings shows that in personal factor, all four variables, self-image congruity, ageing effect, physical attractiveness, and healthcare, are in line with previous studies (Solomon, 2017; Kellner, 2003; Souiden \& Diagne, 2009; Sarpila \& Rasanen, 2011; Sarlio-Lahteenkorva, Silventoinen \& Lahelma, 2004; Harkonen, 2007; Khuong \& Duyen, 2016). In socio-cultural factor, both variables, social beliefs and lifestyle are in line with previous studies (Weber \& de Villebonne, 2002; Souiden \& Diagne, 2009, Alalwan, 2018). For marketing factor, there are two variables which were not significantly affecting men's attitude on the consumption of skincare product, which are celebrity endorsement and online purchase situation. Those findings are not supporting the previous study from Dwivedi, Johnson, and McDonald (2015), which stated that celebrity endorsement is one of the most powerful tools to boost brand equity. But for the result of social media advertising variable, there might be some factors which affecting this characteristic of male consumer in Indonesia, one of them is related to the fact that for male consumer tend to attach the importance of direct communication or consultation when shopping certain product categories (Banyte, et., al, 2015). However, the other two variables, social media advertising and price value are positively affecting the attitude of the men's attitude and are in line with previous studies (Shareef et., al, 2019; Brosdahl \& Carpenter, 2011). Finally, for attitude, finding shows that this variable is positively affecting behavioral intention of the male consumer, which were in line with previous studies (Ajzen \& Fizbein, 2000; Akurtan \& Tezacan, 2012). Based on all of the results obtained, there are several managerial implications, especially in their marketing efforts, cosmetic manufacturers specifically for men must continue to look for and maintain these factors, especially on celebrity factors and online purchasing situations that do not affect consumer attitudes, where the character of the celebrity must have the right character with the expectations of male consumers. for the benefits obtained from the consumption of these skin care products, and

From personal factors it can be concluded that, all variables namely Self-Image Congruity, Aging Effect, Physical Attractiveness and Healthcare, from the sociocultural factors it is concluded that all variables, namely Social Beliefs and Lifestyle, have a positive effect. From the marketing factor, it is concluded that social media advertising and price value are two variables 
which are proven to have a positive effect on Attitude. Meanwhile, the variables Online Purchase Situation and Celebrity Endorsement in this study proved to have no positive influence on Attitude. Price Value is the Variable consider doing proper advertising on online shopping sites, or even doing advertising with the help of social media for sales efforts through online shopping sites.

\section{RESEARCH LIMITATION}

Some limitations of this research should be considered when interpreting the results. From the screening stage, it is lack of celebrity endorsement aspect, this could affect the results on this variable to be biased, because respondents are not filtered optimally, especially on that specific variable. So, it is especially important to pay great attention to every aspect in the study, so that we can get the exact target respondents. From research indicators, specifically on lifestyle variable, which are LS1, LS6, and LS7, still considered too general and do not really reflect lifestyle aspect. LS1 is considered more relevant as an indicator for measuring price sensitivity, LS6 and LS7 are considered more relevant as indicators for measuring social dimensions. To overcome that limitation, it is important for researcher to look for definitions and journals that are really in tune with the ideas and aspects in the study. For example, the research context is "urban" lifestyle, so that the indicators selected are not too general to just become less relevant. Another limitation is the research is only limited to the questionnaire distribution method, so there is a possibility that the results displayed in this study have a time limitation, in the sense that this research cannot necessarily predict the attitudes and behavior of male consumers towards skincare products for the next few years. Last but not the least, it is still rare to find well-publicized studies that specifically discuss and analyze male consumer behavior in the beauty industry, especially in Southeast Asia and even Indonesia. So that the reference source of the research is mostly oriented towards male research in Westerns.

\section{CONCLUSION}

With the greatest relationship value in marketing factors. This means that the male market segmentation has characteristics that are quite sensitive to price values, including in the beauty sector in skincare products. Then the results show that Attitude has a positive and significant effect on behavioral intentions. So, it can be concluded that the attitude of urban men about all aspects related to and directly influencing the formation of urban male consumer attitudes in using skincare products creates consumer behavioral intentions in consuming skincare products.

\section{AUTHORS' CONTRIBUTIONS}

All authors contributed equally to this work.

\section{REFERENCES}

Aeker, A David. (1999). Ekuitas Merek, Edisi Indonesia. Jakarta: Mitra Utama

Ajzen, I. and Fishbein, M. (2000) Attitudes and the Attitude-Behavior Relation: Reasoned and Automatic Processes. European Review of Social Psychology vol. 11. https://doi.org/10.1080/14792779943000116

Alalwan, Dwivedi, Rana, \& Williams. (2016). Consumer adoption of Internet banking in Jordan: Examining the role of hedonic motivation, habit, self-efficacy, and trust. Journal of Financial Service Marketing 20, 145-157. https://doi.org/10.1057fsm.2015.5

Bakewell, Cathy, Mitchel, Vincent Wayne dan Rothwell, Morgan. (2006). UK Generation Y Male Fashion Consciousness. Journal of Fashion Marketing and Management. https://doi.org/10.1108/13612020610667487

Banyte, Jurate, Rutelione, Ausra, and Jaruseviciute, Agne. (2015). Modelling of Male Shoppers Behavior in Shopping Orientation Context. Procedia - Social Behavioral Sciences 213694-701. https://doi.org/10.1016/j.sbspro.2015.11.489

Binwani, Kusboo Janak dan Yin Ho, Jesica Sze. (2019). Effect of Social media on cosmetic brands. Journal of Marketing Advances and Practices 1(2).

Datta, Hema Sharma dan Prames, Rhanges. (2010). Trend in Aging and Skincare, Ayurvedic Concepts. Journal of Ayurveda and Integratice Medicine.

https://doi.org/10.4103/0975-9476.65081

Dini, Tria Anggraini dan Rapotan Hasibuan. (2020). Gambaran Promosi Phbs Dalam Mendukung Gaya Hidup Sehat Masyarakat Kota Binjai Pada Masa Pandemic Covid-19. Jurnal

Menara Medika $3(1)$. https://doi.org/10.31869/mm.v3i1.2194

Dornyei, Zoltan. (2007). Research Methods in Applied Linguistics. Quantitaive, Qualitative, and 
Mixed Methodologies. Oxford: Oxford University Press.

Gomez, Jesicca Brajos, Amando, Jose Benitez dan Montes, Javier Llorens. (2015). Impact of its infrastructure on customer service performance: The Role of micro its Capabilities and Online Customer Engagement. The Pacific Asia Conference on Information Systems (PACIS)

Proceedings 41. Accessed from https://aisle.aisnet.org/pacis2015/41

Grogan, S. (1999). Body Image: Understanding Body Dissatisfaction in Men, Women, and Children. United States: Routledge.

Harkonen, J. (2007). In Search of the Macho-effect: Gender and the Employment Dynamics of Couples. CIQLE Inequality and Life Course Workshop at Yale University, New Haven. Accessed from www.yale.edu/ciqle/CIQLEPAPERS/Mach os.pdf

Hellier, Phillip K, Geursen, Gus M, Carr, Rodney A, and Rickard, John A. (2003). Customer Repurchase Intention: A General Structural Equation Model. European Journal of Marketing vol. 37(11). https://doi.org/10.1108/0309056031049545 6

Intan, Trivena maria Daeng, NN, Mawengkang dan Edmon R, Kalesaran. (2017). Penggunaan Smartphone Dalam Menunjang Aktivitas Perkuliahan Oleh Mahasiswa Fispol Unsrat Manado. Jurnal Acta Diurna 6(1). Accessed on September 2020 from https://ejournal.unsrat.ac.id/index.php/actadi urnakomunikasi/article/view/15482

Khan et al. (2017). Men's attitude and motivation toward consumption of grooming product: A comparison of Chinese and Pakistani male consumers. Cogent Business and Management 4(1) 1309783 https://doi.org/10.1080/23311975/2017.1309 783

Khuong, Mai Ngoc and Duyen, Hoabg Thin My. (2016). Personal Factors Affecting Consumer Purchase Decision towards Men Skin Care Products - A Study in Ho Chi Minh City, Vietnam. International Journal of Trade, Economics, and Finance 7(2). https://doi.org/10.18178/ijtef.2016.7.2.497
Kotler, Philips dan Keller, Kevin Lane. (2011). Manajemen Pemasaran, Edisi 13 Jilid 1 dan 2. Jakarta: Erlangga.

Kotler, Philips. (2003). Manajemen Pemasaran, Edisi Ke-9. Jakarta: PT. Indeks Gramedia

Kotler, Philips dan Keller, Kevin Lane. (2012). Manajemen Pemasaran, Edisi 12. Jakarta: Erlangga

Kotler. Philips dan Amstrong, Gery. (2008). PrinsipPrinsip Pemasaran Jilid 1. Jakarta: Erlangga

Kwan, Fam Lock, Rahila, Ahmad dan Rohijan, Ahmad. (2019). Cosmetic Advertisement: A study on self-esteem and buying behavior of young women in Kuala Lumpur Malaysia. International Journal of Recent Technology and Engineering vol. 7.

Liu, Yan, Zou, Lan, Ma, Lin, Chen, Wen-Hua, Wang, Bo, and Xu, Zun Le. (2006). Synthesis and pharmacological activities of xanthone derivatives as alpha- glucosidase inhibitors. Bioorg Med Chem 15:14(16). https://doi.org/10.1016/j.bmc.2006.04.014

Lisa, Oktaviani, and Arief Sudrajat. (2016). Fenomena Perilaku Belanja Online Sebagai Alternatif Pilihan Konsumsi di Kalangan Mahasiswa Universitas Negeri Surabaya. Paradigma: Jurnal Online Mahasiswa S1 Sosiologi UNESA 4(3). Accessed from https://neliti.com/publications/252448

Malhotra, Naresh. (2010). Riset Pemasaran Pendekatan Terapan, Edisi keempat, Jilid 2. Jakarta: PT Indeks

Marjerison, Rob Kim, Yipei Huang dan Chen, Rong Juan. (2017). The Impact of Social Media Influencers on Purchase Intention Towards Cosmetic Products in China. Asian Journal of Business $\quad$ Research https://doi.org/10.14707/ajbr.170035

Mohanapriya, A, Padmavathi, M dan Rrasatkumar, A. (2019). A comparative study on the impact of skincare products on the self-esteem of women user and non-user in Coimbatore City. International Journal of Recent Technology and Engineering 7(5s) 421-424.

Moungkhem, Chaninton, and Surakiatpinyo. (2010). A Study Factors Affecting on Men's Skin Care Product Purchasing, Particularly in Karlstad, Sweden. Accesed from https://diva- 
portal.org/smash/get/diva2:3280

65/FULLTEXT01.pdf

Ndubisi, Nelson Oly dan Moi, Chiew Tung. (2005). Customers behaviourial responses to sales promotion: The role of fear of losing face. Asia Pacific Journal Marketing and Logistic 17(1) 32-49.

https://doi.org/10.1108/13555850510672278

Peter, J Paul dan Olson, Jerry C. (2003). Perilaku Konsumen dan Strategi Pemasaran. Jakarta: Erlangga

Sarlio-Lähteenkorva, Silventoinen \& Lahelma. (2004). Relative Weight and Income at Different Levels of Socioeconomic Status. American Journal of Public Health 94(3) 468472. https://doi.org/10.2105/ajph.94.3.468

Sarpila, Outi dan Rasanen, Pekka. (2011). Personal Care Consumtion in Finlandia, Trend in the Early 2000s. International Journal of Sociology and Social Policy 31(7/8) 441-455. https://doi.org/10.1108/01443331111149879

Shen, Ke, Geng, Chuan dan Xu, Shinwei. (2019). Antecedents of Residents' Pro-tourism Behavioral Intention: Place Image, Place Attachment, and Attitude. Frontier on Psychology 10:2349. https://doi.org/10.3389/fpsyg.2019.02349

Solomon, Michel R. (2013). Consumer Behavior: Buying, Having and Being, 10th edition. England: Pearson Education Limited.

Souiden,Nizar dan Diagne, Mariam. (2009). Canadian and French Men's Consumption of Cosmetics: A Comparison of Their Attitudes and
Motivations. Journal of Consumer Marketing 26(2) 97-109.

https://doi.org/10.1108/07363760910940465

Sturrock, F. and Pioch, E. (1998). Making Himself Attractive: The Growing Consumption of Grooming Products. Marketing Intelligence and Planning vol. 16(5).

Sukato, Nuntasare dan Elsey, Barry. (2019). A model of male consumer behavior in buying skincare products in Thailand. ABAC Journal 29(1) 39 52.

Supranto, J. (2001). Pengukuran Tingkat Kepuasan Pelanggan untuk Menaikkan Pangsa Pasar. Jakarta: Rineka Cipta.

Tuten, Tracy L, and Solomon, Michael R. (2017). Social Media Marketing Third Edition. Los Angeles: SAGE Publication.

Very, Irawan. (2011). Pengembangan Model Perilaku Konsumen Pria dalam Membeli Produk Perawatan Kulit di Indonesia. Jurnal Ilmu Manajemen 3(1) 16-30. https://doi.org/10.31937/manajemen.v3i1.17 3

Weber, J. M., and de Villebonne, J. C. (2002). Differences in Purchase Behavior between France and the USA: The Cosmetic Industry. Journal of Fashion Marketing and Management vol. 6(4).

Wijayanto, Setyo Hari. (2008). Structural Equation Modeling dengan LISREL 8.8. Yogyakarta: Graha

Ilmu. 